similarly handicapped. Dr. O'Connor, superintendent, Lexington School for the Deaf, reported use of tests and procedures for evaluating the capacity of boys and girls handicapped by deafness to benefit from attendance at ordinary schools. Mrs. Miller (Clarke School) described some methods of social training for senior pupils. An important paper by Prof. Lewis (University of Nottingham) on language perception and reasoning was supported by one from Dr.
Morosova (Moscow), in which she described capacity to use words in thinking as a leading determinant of cognitive activity. Several speakers, including the writer of this article, discussed the achievement of this capacity as a factor in the social development of deaf children, and the deviation of their mental growth from normal when it is begun later than among children who are not deaf.

A. W. G. EwING

\title{
NATURE AND GENETICAL CONTROL OF RESISTANCE IN LIVING ORGANISMS
}

$\mathrm{T}$ HE nature and genetical control of resistance in living organisms was considered at a joint session on September 1 of Sections $D$ and $K$ (Zoology and Botany) of the British Association at the Glasgow meeting. The topics were disease resistance in plants and animals, insecticide resistance in mosquitoes and drug resistance in bacteria.

In the opening paper Dr. P. R. Day (John Innes Horticultural Institution) outlined the types of genetical control of resistance to pathogens in higher plants. These range from the single, usually dominant, gene through complementary action of two or more genes to polygenic control. There is a similar pattern in the genetic control of virulence in fungal pathogens selected by cultivation of resistant crop varieties. At the single-gene level this has led to the suggestion of a gene-for-gene relationship whereby the outcome of host infection by a pathogen depends on the alleles present at complementary loci in both organisms. A resistance gene in the host is only effective if there is a corresponding avirulence gene in the pathogen. An example of how the gene-for-gene concept may be applied comes from work at the University of Wisconsin on the inheritance of avirulence among a group of strains of Venturia inaequalis (apple scab) on seven apple varieties. The genes for avirulence were identified and separated in recombinant stocks. From the results of inoculations it was possible to estimate how many genes for resistance were present in each apple variety and which genes for resistance were common to two or more varieties. The interaction of gene products of the host and pathogen enables the host to recognize that the pathogen is avirulent. This recognition triggers secondary reactions which kill or limit the pathogen growth. Mutants of Cladosporium fulvum (tomato leaf mould) and Melampsora lini (flax rust) can be obtained which presumably avoid the recognition reaction and are thus virulent on a particular host resistant to the original strains.

Miss C. E. Jackson (Ross Institute of Tropical Hygiene) described the appearance of resistance to chlorinated hydrocarbon insecticides (dieldrin, $\mathrm{BHC}$ and DDT) following their use to control natural populations of malaria-carrying anopheline mosquitoes. Laboratory studies showed that resistance to dieldrin in a strain of Anopheles gambiae from Northern Nigeria was some 800 times higher than that of wild-type insects of that species and was controlled by a partially dominant single gene. A discriminating dose of the insecticide enables hybrids to be distinguished from the homozygous resistant parent. DDT resistance in $A$. sundaicus from Java was controlled by a single recessive gene. In laboratory experiments it was possible to raise the level of tolerance of mosquitoes to insecticides by exposures to sublethal doses during twenty generations of larval selection. The level of tolerance achieved was never more than seven times that of the original stock and this fell when larval treatments were stopped. This 'vigour tolerance' may be associated with inversions found in the chromosomes of treated stocks. The importance of this problem is shown by the fact that resistance to the insecticides dieldrin, $\mathrm{BHC}$ and DDT and its analogues is now found in eleven countries in six species of mosquito. No example of simultaneous resistance to DDT and dieldrin or DDT and BHC has yet been proved.

Dr. Mary Barber (Postgraduate Medical School, London) described three types of drug resistance found in bacteria: drug tolerance, drug dependence and drug destruction. The first two types of resistance generally arise by mutation. Drug destruction is often due to formation of an adaptive enzyme such as penicillinase in some penicillin-resistant bacteria. The initiation of enzyme production by strains previously producing none probably results from mutation. The genetic transfer of drug resistance between cells can be accomplished in the laboratory by deoxyribonucleic acid extracts (transformation), by a virus vector (transduction) and by direct transfer of a bacterial chromosome, or parts of it, when cells are in contact (conjugation). The extent of these processes in Nature is unknown, although favourable conditions exist in the human flora or in the soil. The accumulation of drugresistant strains of Mycobacterium tuberculosis and Staphylococcus aureus in hospitals has become a major problem. A study of penicillin-resistant $S$. aureus carried in the noses of pupil midwives in a London hospital showed a rise from 24 per cent carrying such strains during their first two weeks in the hospital to 60 per cent after three months. Of the permanent hospital staff 90 per cent carried resistant S. aureus.

The most successful approach to the control of both bacteria and mosquitoes is likely to be the simultaneous use of two or more drugs or insecticides. This makes it less likely that resistant mutants will develop. Plant breeders also try to release new disease-resistant crop varieties having two or more different resistance genes for the same reason.

Dr. A. Kleczkowski (Rothamsted Experimental Station) surveyed resistance to virus diseases in animals and plants. Resistance in plants is in a special category because of the absence of any immunity reaction comparable to the antibodies of the $\gamma$-globulin fraction of animal serum proteins. 
Plant resistance may be due to failure of symptom expression, to interference, whereby infection with a mild strain protects against infection with a more virulent related virus, or by resistance mechanisms which result in localized death of host tissue preventing virus multiplication. Virus resistance may also be due to the host being inappropriate. Although antibodies may control the spread of virus from cell to cell, virus inside animal cells is not accessible to antibody and its amount is controlled by the rates of virus reproduction and inactivation. At higher temperatures the rate of inactivation tends to predominate and this has been used to cure virus diseases.
Virulent mutants of fungal and virus pathogens, drug-resistant bacteria and insecticide-resistant mosquitoes all arise as a result of high selection pressures. These pressures can be demonstrated even in entirely natural populations, resulting, for example, in the multiplicity of strains of Phytophthora infestans to be found on wild populations of Solanum demissum in Central Mexico.

Undoubtedly more is known about the genetical control of resistance than about its nature at the present time. As more is found out about both. so we shall be better able to use and control resistance.

P. R. DAY

\section{SCIENCE IN SCHOOLS}

$\mathrm{T}$ HE Glasgow meeting of the British Association emphasized the need to reveal and encourage scientific aptitudes from an early age, and, with this in view, a special programme for young people was devised.

The Scottish Branch of the Science Master's' Association arranged an exhibition, open every afternoon, in which typical class apparatus and experiments were demonstrated and explained by boys and girls from Glasgow schools. Both children and teachers took great interest in discovering how other schools carried out familiar experiments and confirmed wellknown principles. At the same time the presence of one or two less-common pieces of apparatus, such as the van de Graaff generator, provided a little extra interest and removed the school-room atmosphere. Unilever, Ltd., had a display of charts, booklets and film-strips which are available for schools, and some of the material advantages of modern science were shown in interesting exhibitions of samples, charts and models provided by Imperial Chemical Industries, Ltd., and the United Kingdom Atomic Energy Authority.

Each afternoon of the meeting three special children's lectures were delivered concurrently, and on August 28 the boys and girls had the difficult choice of hearing Sir Lawrence Bragg on "How we hear and speak", Dr. H. Barnes on "Under-water Television" or Mr. A. E. Gunther on "Geology and Oil". Those with tickets for August 29, September 1 and 2 were in no less difficulty, since they had to choose from the following list: "Atomic Energy" by Dr. T. E. Allibone, "Prehistoric Animals" by Dr. W. E. Swinton, "Thunderstorms, Hail and Lightning" by Dr. B. J. Mason, "Exploring Flowers" by Dr. G. Taylor, "Man-made Fibres" by Mr. A. B. Thompson, "The Electronic Brain" by Dr. A. D. Booth, "Animal Clocks and Compasses" by Dr. J. D. Carthy, and "Man in Flight" by Wing-Commander P. D. G. Whittingham.

One of the features of the meeting was an open forum held on Saturday morning. Sir Alexander Fleck introduced the chairman, Dame Kathleen Lonsdale, and her panel of experts consisted of Dr. I. J. Faulkner, Mr. B. B. Lloyd, Dr. B. J. Mason and Dr. W. E. Swinton. The questions, sent in by schools in the west of Scotland, showed pronounced topicality with considerable emphasis on space travel and satellites, but the panel also had to deal with some searching questions on the nature of colour, world population and the possibility of extinction of the human species. Some uncertainty was evident among the panel when asked to define matter, but Dr. Swinton was in no doubt that the homing instinct in the pigeon was in no way due to any extra sense organ in the bird.

On Tuesday morning, at the invitation of Section $X$, some sixth-form boys read original papers. Mr. A. M. J. Hutchings and Mr. A. J. Nicholl, of the High School of Glasgow, dealt very authoritatively with "Plant Ecology of Heather, Moor and Bog", while Mr. Alan Nicol gave a concise account of "The Production of Special Steels", as did Mr. J. C. Natzio with "The Work of Discovery $I I "$ ". Both these speakers are scholars of Hutcheson's Boys' Grammar School, Glasgow. Mr. D. W. McCredie of Charterhouse read an excellent paper on "The Breeding Habits of the Hen Harrier in South-West Perthshire".

At a conference of affiliated societies, Mr. R. A. Stevens outlined the future policy of the British Association with regard to the Junior B.A. The plan requires the setting up of area committees (several are already in being and eight or nine are expected by the end of the year), which would work in cooperation with local societies to provide lectures, meeting places and organized excursions. In addition to supplying the needs of adult audiences, these area committees will do all they can to encourage school scientific societies to expand and to serve as a centre of scientific culture in the schools from which interest in science would emanate downwards into the junior classes and across into the arts side of the school. In order to give the fullest assistance to scientific societies in schools, the British Association is setting up a committee for the purpose of devising suitable visual aids, and local societies are being encouraged to organize federations of school societies in their areas for the pooling of resources and exchange of ideas. Such a plan, it is felt, would be of great value to the adult societies since it would lead the children towards them and ultimately provide a source of recruits.

It is recognized by the British Association that the present plan of holding the Junior B.A. meeting at the same time as that of the parent body is possible only in the circumstances existing in Glasgow, where the city schools have just started the new term. To hold such meetings either in the school holidays or in mid-term would be quite impracticable, and it is proposed that in future the junior meeting shall be held at the end (or beginning) of the school year in whatever area is acting as host that year.

ERIC WALkER 